\title{
FATIGUE CALCULATION FOR WELDED JOINTS OF BEARING ELEMENTS OF FREIGHT CAR BOGIE
}

\author{
L.M. LOBANOV, O.V. MAKHNENKO, G.Yu. SAPRYKINA and A.D. PUSTOVOJ \\ E.O. Paton Electric Welding Institute, NASU \\ 11 Bozhenko Str., 03680, Kiev, Ukraine. E-mail: office@paton.kiev.ua
}

\begin{abstract}
Statistics of accident rate at Ukrainian and Russian railways is an evidence of increase in the recent years of the accidents, related with failure of cast bearing elements of two-axle three-component freight car bogies. Analysis of service reliability of cast structures of side frame and bolster of 18-100 type bogie shows that appearance of fatigue cracks is the main reason of reject. It is reasonable to search an alternative application of welding technologies in manufacture of indicated parts from sheet products for the purpose of increase of their safety and survivability. It is shown that existing Norms for designing of welded joints and assemblies of railway cars significantly overstate real cyclic load resistance of welded joints in comparison with the Recommendations of the International Institute of Welding. This disadvantage is typical for number of reference documents acting in Russia and Ukraine, which regulate calculation of fatigue resistance of welded joints and assemblies. This promotes negative results in designing with respect to required life of welded elements. Development of safe and technological welded elements of freight car bogie requires application of the recent achievements in the field of fatigue strength of welded joints. 13 Ref., 4 Tables.
\end{abstract}

$\boldsymbol{K} \boldsymbol{e} \boldsymbol{y} \boldsymbol{w} \boldsymbol{o r d} \boldsymbol{s}:$ welded structures, welded joint, freight car, three-element bogie, side frame, frame failure, fatigue resistance, stress amplitude

Statistics of accident rate at Ukrainian and Russian railways is an evidence of increase in the recent years of the accidents, related with failure of cast bearing elements of two-axle three-component freight car bogies. Analysis of service reliability of cast structures of side frame and bolster of 18-100 type bogie and its modifications shows that appearance of fatigue cracks is the main reason of reject $[1,2]$. Increase of fatigue resistance and survivability of the bogie bearing elements is extremely relevant.

Using of welding technologies for manufacture of indicated parts from sheet products for increase of their service reliability characteristics under alternating loads is promising [3].

Welded structures of the freight car bogies are widely used in Western Europe. The attempts were made in Ukraine and Russia on development of structures of all-welded bearing elements of two-axle three-component freight car bogies, which can replace the cast structures [4-8]. However, any of the developed welded structures of side frames and bolster is not used today in regular tracking industry, since their structures in most cases had insufficient optimizing from point of view of welded joint fatigue resistance.

Safety of welded variant of bearing components should be provided in development of competitive welded structures of the bearing ele- ments, which can replace the cast elements of 18-100 type bogie, due to increase of resistance and survivability in comparison with the cast structure. Calculation of fatigue resistance of developing all-welded structures of the elements of freight car bogie is regulated using acting Ukrainian and Russian Norms of calculation and design of $1520 \mathrm{~mm}$ track railway cars of Ministry of Railways (non-self-propelled) [9] (further the Norms) based on coefficients of margin of fatigue resistance for different zones of evaluation (base metal and welds) considering distribution of coefficient of vertical dynamics in the ranges of service rates (loading spectrum).

Unfortunately, real cyclic load resistance of the welded joints is significantly overstated in acting Norms for designing of welded joints and assemblies of the railway cars, that promotes negative results of designing with respect to required life.

The values of these loads depend on car movement speed, condition of track etc., i.e. there is a whole spectrum of cyclic loads, elements of which have different appearance probability in time of car servicing. This problem is sufficiently well studied and the Norms include the corresponding recommendations, allowing quantity determination of power characteristics of cyclic loading under service conditions. Disadvantage of the Norms is the recommendations with respect to values of cyclic load resistance of bearing welded joints. 
Table 1. $\left(\bar{K}_{\sigma}\right)_{\alpha}$ value for some typical elements of bearing structures of cars in accordance with Norms [9]

\begin{tabular}{||c|c||}
\hline \multicolumn{1}{|c|}{ Characteristics of element and calculation zone } & $\left.\bar{K}_{\sigma}\right)_{\alpha}$ \\
\hline Standard sample with polished surface on GOST 25.502-79 & 1.0 \\
\hline Rolling or cast strip with $20 \mathrm{~cm}^{2}$ section without stress concentrators along base metal & $1.3-1.5$ \\
\hline $\begin{array}{l}\text { Bolsters from structural shapes (flange, channel, zed, angle) and blanked from sheet products along flange } \\
\text { base metal (far from stress concentrators) }\end{array}$ & $1.3-1.5$ \\
\hline $\begin{array}{l}\text { Box bolsters, welded from structural shapes and blanks by butt welds along upper and lower flanges without } \\
\text { transverse stiffeners and diaphragms, along weld }\end{array}$ & $1.4-1.6$ \\
\hline $\begin{array}{l}\text { Box bolsters, welded from structural shapes by fillet welds without transverse stiffeners and diaphragms, along } \\
\text { weld }\end{array}$ & $1.5-1.7$ \\
\hline $\begin{array}{l}\text { Bolsters from structural shapes and blanks, bands of box bolsters from sheet products, welded by double-sided } \\
\text { straight transverse butt welds, in weld zone }\end{array}$ & $2.0-2.4$ \\
\hline $\begin{array}{l}\text { The same, double-sided } 45^{\circ} \text { scarf welds } \\
\text { The same, double-sided straight welds, treated flush with base metal surface }\end{array}$ & $1.8-2.2$ \\
\hline The same, one-sided straight welds (with lack of root penetration or without root run) & $1.5-1.7$ \\
\hline
\end{tabular}

Fatigue limit $\sigma_{\mathrm{a}, N}$ (on amplitude) in the Norms, under condition that $\sigma_{\mathrm{a}, N}$ corresponds to non-failure probability $P=0.95$, for welded frames and bolsters from sheet and structural shapes in use of semi-automatic and manual welding, is

$$
\sigma_{\mathrm{a}, N}=\frac{\bar{\sigma}_{-1}}{\left(\bar{K}_{\sigma}\right)_{\alpha}}\left(1-z_{\mathrm{d}} v_{\sigma}\right)
$$

where $\bar{\sigma}_{-1}$ is the average (median) value of fatigue limit of smooth standard sample from part material (on GOST 25.502-79) at symmetric cycle of bending $(R=-1.0)$ on $N$ cycle basis; $\left(\bar{K}_{\sigma}\right)_{\alpha}$ is the average value of coefficient of reduction of fatigue limit of part in relation to fatigue limit of standard sample; $z_{\mathrm{d}}$ is the $\sigma_{\mathrm{a}, N}$ reciprocal distribution as random quantity; $v_{\sigma}$ is the coefficient of variation of fatigue limit under condition that $\sigma_{\text {a. } N}$ corresponds to non-failure probability $P=$ $=0.95\left(\left(1-z_{\mathrm{d}} v_{\sigma}\right)=0.88\right)$.

Data from the Norms [9] on $\left(\bar{K}_{\sigma}\right)_{\alpha}$ value for typical elements of car bearing structures are given in Table 1.

It follows from dependence (1) that, since $\bar{\sigma}_{-1}(N)$ depends on strength of base metal and rise with $\sigma_{t}$ growth, then user of the Norms can suppose that increase of structural steel strength $\sigma_{\mathrm{t}}$ promotes, according to (1), rise of $\sigma_{\mathrm{a}, N}$. Meanwhile, a well-known fact is clearly indicted in the IIW Recommendations [10] based on processing of number of experimental data. It is a provision that $\sigma_{\mathrm{a}, N}$ value at sufficiently representative sample of tests does not depend on $\sigma_{t}$ for untreated welded joints of structural steels of ferrite (pearlite) classes of strength limit $\sigma_{t}$ from 400 to $900 \mathrm{MPa}$. Thus, low-cycle fatigue resistance of the welded joints will be approxi- mately the same for welded frame and bolster from low-carbon steel, having strength limit $\sigma_{t}=$ $=400 \mathrm{MPa}$, and from high-strength low-alloy steel with $\sigma_{\mathrm{t}}=900 \mathrm{MPa}$.

There are also significant remarks in relation to values of $\left(\bar{K}_{\sigma}\right)_{\alpha}$ coefficients, recommended for welded joints in the Norms. Thus, $\left(\bar{K}_{\sigma}\right)_{\alpha}$ value at 1.5-1.7 level is recommended for longitudinal welded joints of the bolsters, manufactured from sheet products, i.e. for steel with $\sigma_{t}=450 \mathrm{MPa}$ and $\bar{\sigma}_{-1}=225 \mathrm{MPa}$ on $10^{7}$ cycle basis, $\sigma_{\mathrm{a}, N}$ value for welded joints according to (1) equals

$$
\sigma_{\mathrm{a}, N}=\frac{225}{1.7} \cdot 0.88=117 \mathrm{MPa} .
$$

The fatigue limit (on amplitude) on $2 \cdot 10^{7} \mathrm{cy}-$ cle basis for the welded joints following the IIW Recommendations [10] is

$$
\sigma_{\mathrm{a}, N}=0.5 \operatorname{FAT} f(R) f(N),
$$

where FAT is the fatigue limit (on range) on $2 \cdot 10^{6}$ cycle basis at symmetric cycle, determined by welded joint class (Table 2); $f(R)$ is the function of coefficient of asymmetric cycle of loading $R$ and level of residual stresses. $f(R)$ value at $R=-1.0$ lies in $f(R)=1.6$ level at residual stress less than 0.2 , and $f(R)=1.0$ at higher residual stresses; $f(N)$ is the parameter, considering limited fatigue. $f(N)$ in the range of $10^{4}<N<$ $<10^{8}$ cycles is determined by dependence

$$
f(N)=\left(\frac{C}{N}\right)^{1 / m},
$$

where $N$ is the welded joint life; $C=2 \cdot 10^{6}, \mathrm{~m}=$ $=3$ at $10^{4}<N<10^{7}$ cycles. It can be assumed that amplitude is not changed at $N>10^{7}$ cycles.

Thus, $\sigma_{\mathrm{a}, N}$ according to [10] does not exceed $26 \mathrm{MPa}$ for longitudinal welded joints of bolsters 
INDUSTRIAL

Table 2. Fragments of FAT values for different welded joints from IIW Recommendations [10]

\begin{tabular}{|c|c|c|c|}
\hline Number & Part sketch & Description & $\begin{array}{l}\text { FAT (for } \\
\text { steel) }\end{array}$ \\
\hline 300 & \multicolumn{3}{|c|}{ Fillet (tee) welded joints with longitudinal loading } \\
\hline 321 & & $\begin{array}{l}\text { Longitudinal continuous welds with double-bevel groove, automatic } \\
\text { welding without interruptions, non-destructive testing (stresses in the } \\
\text { flange) }\end{array}$ & 125 \\
\hline 322 & & $\begin{array}{l}\text { Longitudinal continuous welds without double-bevel groove, automatic } \\
\text { welding without interruptions, non-destructive testing (stresses in the } \\
\text { flange) }\end{array}$ & 100 \\
\hline 323 & & $\begin{array}{l}\text { Longitudinal continuous fillet welds, manual welding with double-bevel } \\
\text { groove and without it (stresses in the flange) }\end{array}$ & 90 \\
\hline 200 & & Butt joints (transverse loading) & \\
\hline \multicolumn{4}{|c|}{ Butt joints (transverse loading) } \\
\hline 211 & & $\begin{array}{l}\text { Weld with transverse loading, double-vee groove or single-bevel V- } \\
\text { preparation, removed reinforcement. } 100 \% \text { non-destructive testing }\end{array}$ & 112 \\
\hline 212 & & $\begin{array}{l}\text { Transverse weld, flat welding under workshop conditions. Non-destructive } \\
\text { testing, weld reinforcement }<0.1 \text { of thickness }\end{array}$ & 90 \\
\hline 213 & & $\begin{array}{l}\text { Transverse weld, which does not satisfy condition No. } 212 \text {. Non-destructive } \\
\text { testing. } \\
\text { Note: weld with angle of reinforcement } \leq 50^{\circ} \text {, welds with reinforcement } \\
\text { angle }>50^{\circ}\end{array}$ & 80 \\
\hline \multicolumn{4}{|c|}{ One-sided joints } \\
\hline 214 & & Transverse weld with non-consumable backing, root crack & 80 \\
\hline 215 & & $\begin{array}{l}\text { Transverse weld on permanent backing, fastened at }>10 \mathrm{~mm} \text { distance from } \\
\text { plate end. } \\
\text { Same, }<10 \mathrm{~mm} \text { from plate end }\end{array}$ & $\begin{array}{l}71 \\
63\end{array}$ \\
\hline 216 & & $\begin{array}{l}\text { Transverse butt welds, one-side welding, without backing, full penetration. } \\
\text { Root is controlled by non-destructive methods without non-destructive } \\
\text { testing }\end{array}$ & 71 \\
\hline
\end{tabular}

at $\mathrm{FAT}=90-125 \mathrm{MPa}, f(R)=1.0$ and $f(N)=$ $=0.585\left(N=10^{7}\right.$ cycles $)$.

Respectively, allowable amplitudes $\left[\sigma_{\mathrm{a}, N}\right]=$ $=\sigma_{\mathrm{a}, N} / n$, where $n$ is the coefficient of safety. $n$ values on the Norms are taken in the ranges 1.31.8 for elements of car bodies of all types depending on level of data reliability on $\sigma_{\mathrm{a}, N}$, and $n=2$ is recommended for new structures. Safety coefficient is set in $n=1.15-1.40$ ranges for critical structures on IIW Recommendations. The respective allowable amplitudes are received for considered longitudinal welded joints under such an assumption:

$$
\begin{gathered}
{\left[\sigma_{\mathrm{a}, N}\right]=117 / 2=58.5 \mathrm{MPa}} \\
\text { and }\left[\sigma_{\mathrm{a}, N}\right]=\frac{26}{1.15-1.40}=24-19 \mathrm{MPa} \text {. }
\end{gathered}
$$

It can be seen that allowable values of amplitudes of nominal stresses $\left[\sigma_{\mathrm{a}, N}\right]$ at regular alter- nating loading on $10^{7}$ cycle basis for longitudinal welded joints of bolsters according to the Norms are $145-210 \%$ higher of that on IIW Recommendations.

Comparison of allowable $\left[\sigma_{\mathrm{a}, N}\right]$ values for one- and double-sided butt welds, located transverse with respect to effect of nominal stresses, was carried out similarly to longitudinal welded joints. The results of comparison, presented in Table 3, confirm that real cyclic load resistance of the welded joints is significantly overstated in the acting Norms. Such examples show that life of welded bearing structures of the railway cars, designed in the ranges of the Norms, can be insufficient. Probably, it is one of the reasons why safe and technological structures of the allwelded bearing elements of three-component freight car bogie, capable to compete with the cast parts, have not been developed yet. 
Table 3. Comparison of allowable values of amplitudes of nominal stresses $\left[\sigma_{\mathrm{a}, N}\right]$ at regular alternating loading on $10^{7}$ cycle basis for different welded joints by the Norms [9] and DBN [11] as well as IIW Recommendations for structures from steel with tensile strength $\sigma_{t}=450 \mathrm{MPa}$

\begin{tabular}{|c|c|c|c|c|c|c|}
\hline \multirow{2}{*}{ Type of welded joint } & \multicolumn{2}{|c|}{ Norms [9] (at $n=2)$} & \multicolumn{3}{|c|}{ IIW Recommendations [10] } & \multirow{2}{*}{$\begin{array}{r}\text { DBN [11] } \\
(\text { at } n=2)\end{array}$} \\
\hline & $\left(\bar{K}_{\sigma}\right)_{\alpha}$ & {$\left[\sigma_{\mathrm{a}, N}\right], \mathrm{MPa}$} & FAT, $\mathrm{MPa}$ & $n$ & {$\left[\sigma_{\mathrm{a}, N}\right], \mathrm{MPa}$} & \\
\hline Longitudinal fillet & $1.5-1.7$ & $58-66$ & $90-125$ & $\begin{array}{l}1.15 \\
1.40\end{array}$ & $\begin{array}{l}26-32 \\
19-23\end{array}$ & 23 \\
\hline Transverse double-sided butt & $2.0-2.4$ & $41-50$ & $80-112$ & $\begin{array}{l}1.15 \\
1.40 \\
\end{array}$ & $\begin{array}{l}23-28 \\
15-20 \\
\end{array}$ & 33 \\
\hline Transverse one-sided butt & $4.0-4.8$ & $21-35$ & $36-80$ & $\begin{array}{l}1.15 \\
1.40\end{array}$ & $\begin{array}{c}17-20 \\
7.5-9.0\end{array}$ & 16 \\
\hline
\end{tabular}

Positive experience of application of IIW Recommendations in development of welded structures of freight car bogies should be noted. In 2002 GSKBV Ltd. (Mariupol, Ukraine) together with SUE «Vagony» (St.-Petersburg, RF) developed a new welded structure of three-element bogie of 18-1711 model with $25 \mathrm{tf}$ axis loading [12]. Primary pilot samples of the bolsters did not pass bench fatigue tests. Thus, all-welded structure of the bolster was improved by the PWI specialists from point of view of increase of fatigue resistance of its welded joints [13]. Further, short-cut accelerated cyclic load tests were carried out for two pilot samples of the bolster. As a result, $30 \mathrm{~mm}$ length macrocrack was found in the first bolster at $2.745 \cdot 10^{6}$ cycles, and no macrocrack was found after $6 \cdot 10^{6}$ cycles of loading in the second bolster, and the tests were stopped. Thus, carried tests showed that developed welded structure of the bolster provides for necessary life and it is inferior to cast one on strength and weight indices and can be recommended for performance of full cycle of tests.

One of the documents acting in Ukraine and regulating calculation of fatigue resistance of ele- ments of steel structures, including welded ones, is the State building standards (DBN) [11]. According to this document, boundary allowable quantity of cycles $N_{i}$ in calculation of total failure rate of the steel structures is calculated in the following way:

$$
N_{i}=\frac{A_{\mathrm{\rho}} \cdot 10^{3}}{\ln \left[\frac{2 \sigma_{\mathrm{a} i}}{\left(1-\rho_{i}\right) R_{\rho i}}\right]}-B_{\rho} \cdot 10^{3},
$$

where $\sigma_{a, i}$ is the amplitude stresses of cycle; $\rho$ is the cycle asymmetry; $R_{\rho i}$ is the calculation fatigue limit of section being calculated, determined on formulae

$$
R_{\rho}=\frac{2 \sigma_{-1}}{2-D_{n}(1+\rho)}\left(1-1.63 \frac{S_{\sigma_{-1}}}{\sigma_{-1}}\right)
$$

where values of parameters $\sigma_{-1}, D_{n}, S_{\sigma_{-1}}$ are taken from Tables of [11]; $A_{\rho}$ and $B_{\rho}$ are the parameters, which are set in Tables of [11]. At that, base metal, welded joints, high-strength bolted joints of elements and assemblies of the structures are divided on groups considering effect of forces

Table 4. Some groups of elements and joints during fatigue calculation [11]

\begin{tabular}{|c|l|}
\hline $\begin{array}{c}\text { Scheme of element and position of } \\
\text { section being calculated }\end{array}$ & $\begin{array}{l}\text { Sections of double-tee, tee and other types, welded by continuous } \\
\text { longitudinal band welds at force application along weld axis }\end{array}$ \\
\hline Butt weld, produced on backing sheet, at loading applied normal to weld line & Butt untreated weld at loading applied normal to weld line, at that joined \\
\hline
\end{tabular}


with respect to calculation section and following the structural-technological characteristics. Table 4 shows groups of elements of different joints [11].

Thus, according to [11] the fatigue limit on $10^{7}$ cycle basis will equal $42 \mathrm{MPa}$ for longitudinal fillet welded joints of bolsters in cycle asymmetry $\rho=-1$ and $\sigma_{-1}=62 \mathrm{MPa}, S_{\sigma_{-1}}=12 \mathrm{MPa}$ and $D_{n}=0.89$ coefficients from expression (5).

Allowable amplitudes of nominal stresses $\left[\sigma_{\mathrm{a}, N}\right]$ equal an amplitude of cycle stresses $\sigma_{\mathrm{a}, i}$ at regular alternating loading on $10^{7}$ cycle basis and $\rho=-1$, and can be determined from dependence (4)

$$
\begin{gathered}
\sigma_{\mathrm{a}, i}=\exp \left(\frac{A_{\rho} \cdot 10^{3}}{10^{7}+B_{\rho} \cdot 10^{3}}\right) \frac{\left(1-\rho_{i}\right) R_{\rho}}{2}= \\
\exp \left(\frac{525 \cdot 10^{3}}{10^{7}+470 \cdot 10^{3}}\right) \frac{(1+1) \cdot 42}{2}=45(\mathrm{MPa}) .
\end{gathered}
$$

In order to obtain more specific calculation of the allowable amplitudes of nominal stresses for side frames and bolsters of railway bogies based on DBN [11], the values received on formulae (4), for such critical structures, should be divided on safety coefficient $n=2$. Table 3 includes the values of the allowable amplitudes of nominal stresses $\left[\sigma_{\mathrm{a}, N}\right]$ according to [11] for different welded joints without heat treatment in comparison with data from the acting Norms and IIW Recommendations. It can be seen that calculation of fatigue resistance of the welded joints based on DBN [11] provides for more conservative results in comparison with the Norms [9], which significantly overstate real cyclic load resistance of the welded joints that can result in errors in designing of new welded structures of bearing elements of the freight car bogies.

\section{Conclusions}

1. Development of all-welded structures of bearing elements of the freight car bogie, which may replace cast elements of 18-100 type bogie, can provide for increase of their reliability and life, reduction of weight and accuracy of coordinating dimension of side frame in the ranges of one dimension type. Implementation of production of the bogie elements using welding technology is not so cost consuming in comparison with casting technology that can create conditions for market saturation with quality elements of the freight bogie.

2. Welded structures of bearing elements of the railway freight car bogies, designed in scope of the acting Norms, can have insufficient life, which is conformed by practice.

3. Designing of safe and technological welded elements of the freight car bogie requires application of the recent developments in area of welded joint fatigue strength. The acting Norms of calculation and designing of railway cars, in particular for the welded joints of these structures, demand thoroughgoing working up, considering information of the International Institute of Welding (IIW Recommendations).

1. Pranov, V.A. (2012) Increase of fatigue life of side frame of freight car bogie: Syn. of Thesis for Cand. of Techn. Sci. Degree. Ekaterinburg: UralGURS.

2. Sokolov, A.M. (2012) About formation of complex program of research on problem of side frame fractures of freight car bogies. Byull. Obied. Uch. Soveta OAO RZhD, 3, 3-11.

3. Makhnenko, O.V., Saprykina, G.Yu., Mirzov, I.V. et al. (2014) Prospects for development of load-carrying elements of freight car bogie. The Paton Welding J., 3, 33-38.

4. Volkov, V.A., Chepurnoj, A.D., Bubnov, V.M. et al. Two-axle bogie for freight cars. Pat. 2275308 RU. Publ. 27.04.2004.

5. Khominich, V.S., Trojnikov, M.A., Bogdanov, V.P. Side frame of freight car bogie. Cert. on utility model 37683 U1 RU. Publ. 10.05.2004.

6. Dejneko, S.Yu., Prikhodko, V.I., Bondar, N.A. et al. Two-axle bogie of freight car. Pat. 2246416 C2 RU. Int. Cl. K7 B61F5. Publ. 20.06.2004.

7. http://Www.nvc-vagon.ru

8. Sharapov, A.A., Goloviznin, B.L., Malykh, N.A. et al. Freight car bogie, side frame and bolster of freight car bogie. Pat. 2373091 C2 RU. Int. Cl. K7 B61F5. Fil. 04.10.2007. Publ. 20.11.2009.

9. (1995) Norms of calculation and design of $1520 \mathrm{~mm}$ track railway cars of Ministry of Railways (nonself-propelled). Moscow: GosNIIV-VNIIZhT.

10. (2006) Recommendations for fatigue design of welded joints and components. IIW Doc. XIII1965r14-03 XV $-1127 r 14-03$

11. (2011) DBN V.2.6-163:2010: Structures of constructions and buildings. Steel structures. Standards of design, production and assembly. Kyiv: Minregionbud of Ukraine.

12. Volkov, V.A., Chepurnoj, A.D., Bubnov, V.M. et al. Two-axle bogie for freight cars. Pat. 2275308 RU. Int $\mathrm{Cl}$. K7 $\mathrm{B} 61 \mathrm{~F} 5 / 38 ; \mathrm{B} 61 \mathrm{~F} 5 / 26 ; \mathrm{B} 61 \mathrm{~F} 5 / 12$; B61F3 / 02. Publ. 27.04.2004.

13. Makhnenko, V.I., Garf, E.F., Rimsky, S.T. et al. (2006) Welded freight bogie bolster project. The Paton Welding J., 4, 2-8.

Received 02.06.2014 